\title{
PENGARUH PENGGUNAAN TEPUNG EMPING MELINJO ( Gnetum gnemon ) DALAM PAKAN TERHADAP KADAR GLUKOSA DARAH DAN ENERGI METABOLIS AYAM KAMPUNG
}

Efronius Biesumanto; Dyah Lestari Yulianti; Permata Ika Hidayati; Tri Ida Wahyu Kustyorini Fakultas Peternakan, Universitas Kanjuruhan Malang, J1. S. Supriadi No.48 Malang Email: dyah_ly@gmail.com

\begin{abstract}
ABSTRAK
Tujuan penelitian ini untuk mengevaluasi penggunaan Tepung Emping Melinjo (TEM) sebagai bahan pakan alternatif dalam ransum terhadap penampilan produksi ayam kampung.Materi yang digunakan adalah 80 ekor DOC ayam kampung. DOC ayam kampung dikelompokkan berdasarkan perlakukan penelitian yaitu penggunaan TEM dalam ransum sebanyak $0 \%\left(\mathrm{P}_{0}\right), 5 \%$ $\left(\mathrm{P}_{1}\right), 10 \%\left(\mathrm{P}_{2}\right)$, dan $15 \%\left(\mathrm{P}_{3}\right)$. Penelitian dirancang menggunakan rancangan acak lengkap terdiri atas empat perlakuan dan empat ulangan. Masing-masing unit percobaan terdiri atas lima ekor ayam. Bahan pakan penyusun pakan basal terdiri atas jagung pipilan, dedak, dan konsentrat ayam kampung. Parameter yang diamati adalah: Kadar glukosa darah (mg/dl), dan Energi Metabolis ( $\mathrm{kkal} / \mathrm{kg}$ ). Ternak dipelihara dalam kandang percobaan selama enam minggu.Data hasil pengamatan ditabulasi dan dianalisis menggunakan analisis ragam, jika antar perlakuan ditemukan perbedaan dilanjutkan dengan uji Duncan.Hasil penelitian menunjukkan bahwa penggunaan TEM dalam ransum tidak memberikan pengaruh terhadap Energi Metabolis $(\mathrm{P}>0.05)$ namun berpengaruh nyata $(\mathrm{P}<0.05)$ terhadap Kadar glukosa darah.Berdasarkan hasil penelitian dapat disimpulkan bahwa penggunaan TEM sebesar $15 \%$ dalam pakan memberikan pengaruh terhadap Kadar Glukosa Darah ayam kampung.Disarankan untuk melakukan penelitian lanjutan tentang peningkatan persentase penggunaan TEM sebagai sumber energi alternatif pakan unggas.

Kata kunci: Tepung emping melinjo, ayam kampung, bahan pakan alternatif
\end{abstract}

\section{EFFECT OF USE OF MELINJO FLAKE MEAL (Gnetum gnemon) ON GLUCOSE CONTENT AND ENERGY METABOLIS OF LOCAL CHICKEN}

\begin{abstract}
The purpose of this study was to evaluate the use of Melinjo (Gnetum gnemon) Flake Meal as an alternative feed ingredient in rations on the local chicken performance. The material used is $80 \mathrm{DOC}$ local chicken. DOC of local chicken is grouped based on research treatment that is the use of melinjo flake meal in ration as much as $0 \%\left(\mathrm{P}_{0}\right), 5 \%\left(\mathrm{P}_{1}\right), 10 \%\left(\mathrm{P}_{2}\right)$, and $15 \%\left(\mathrm{P}_{3}\right)$. The study was designed using a complete randomized design consisting of four treatments and four replications. Each experimental unit consists of five chickens. The feed ingredients of basal feed composition consist of yellow corn, bran, and local chicken concentrate. The parameters observed were:blood glucose level (mg/dl) and Energy Metabolis ( $\mathrm{kkal} / \mathrm{kg}$ ). Birds was kept in a trial cage for six weeks. The observational data were tabulated and analyzed using the variance analysis, if the treatment was found to be different, followed by Duncan test. The results showed that the use of melinjo flake meal in ration did not give effect to energy metabolis $(\mathrm{P}>0.05)$ but had significant effect $(\mathrm{P}<0.05)$ blood glucose. Based on the results of research can be concluded that the use of $15 \%$ melinjo flake meal in the feed gives the best influence on the blood glucose of chicken production. It is recommended to conduct further research on increasing the percentage of melinjo flake meal as an alternative source of poultry feed.
\end{abstract}

Keywords: Melinjo flake meal, chicken, alternative feed ingredients. 


\section{Jurnal Sains Peternakan}

Vol 6 No 2, Desember 2018, 50-56

ISSN 2579-4450

\section{Pendahuluan}

Keberhasilan usaha peternakan unggas dipengaruhi oleh tiga faktor, yaitu: bibit, pakan, dan manajemen pemeliharaan. Penyediaan ransum yang berkualitas ternyata masih menemui banyak kendala sampai saat ini karena sebagian bahan baku pakan

masih diperoleh melalui mekanisme impor yang sangat dipengaruhi oleh ketersediaan dan harga yang berfluktuatif. Dalam budidaya unggas, biaya untuk pakan menempati porsi terbesar dari total biaya, yaitu sekitar $70-80 \%$, dimana bahan baku pakan ternak masih diperoleh melalui mekanisme impor. Berdasarkan data yang dirilis oleh Departemen Pertanian RI jumlah bahan pakan yang diperoleh secara impor, yaitu: jagung 51,4\%, bungkil kedelai 18\%, tepung ikan 5\%, Corn Gluten Meal (CGM) 7,0\%, premix 0,6\%, dan Crude Palm Oil (CPO) 2\%, dan selebihnya dedak (Ditjennak, 2010). Upaya untuk mengatasi masalah tersebut dapat dilakukan dengan mencari bahan baku alternatif yang murah, mudah didapat, mempunyai nilai kandungan nutrisi tinggi, penggunaan tidak bersaing dengan kebutuhan manusia dan mempunyai pengaruh yang baik pada ternak.

Salah satu upaya yang dapat dilakukan adalah mencari bahan pakan alternatif (non-konvensional) yang harganya relatif lebih murah.Bahan pakan alternatif (nonkonvensional) tersebut dapat berasal dari tepung (by-product) pertanian dan industri.Salah satu tanaman hortikultura yang memiliki potensi besar untuk dikembangkan adalah melinjo (Gnetum genemon, $L$.).

Tanaman melinjo di beberapa daerah selain sebagai penghasil tanaman sayuran melinjo juga merupakan sumber bahan baku pembuatan emping melinjo. Emping melinjo merupakan salah satu bahan makanan ringan, selain bernilai gizi tinggi juga memiliki cita rasa yang banyak disukai masyarakat. Emping melinjo merupakan makanan istimewa dalam pola makanan rakyat Indonesia. Kandungan gizi dan vitamin yang terdapat dalam makanan yang berasal dari emping melinjo meliputi ; kalori, karbohidrat, protein, lemak, kalsium, fospor, besi, vitamin B, dan lemak siklopropen (cyclopropene fatty acid) (Aliudin dan Anggraeni, 2012).

Industri skala rumah tangga yang mengolah emping melinjo banyak ditemukan di Jawa Tengah dan Jawa Timur.Tepung yang dihasilkan dari industri pengolahan emping melinjo tersebut adalah produk afkir proses pengolahan biji melinjo menjadi emping yang hancur akibat proses penumbukan.Tepung tersebut sedianya sudah dimanfaatkan oleh beberapa peternak sebagai bahan pakan untuk ternak unggas, namun publikasi hasil studi empiris yang bersifat ilmiah belum ditemukan. 
Bahan pakan ternak unggas dibagi menjadi dua kelompok, yaitu bahan pakan sumber energi dan bahan pakan sumber protein. Konsentrat adalah suatu bahan makanan yang dipergunakan bersama bahan pakan lain untuk meningkatkan keserasian gizi dari keseluruhan makanan dan dimaksudkan untuk disatukan dan dicampur sebagai suplemen (pelengkap) atau makanan lengkap (Hartadi, Reksohadiprodjo, dan Tillman 2005).

Untuk meningkatkan dan mengembangkan emping melinjo dapat dilakukan dengan cara ekstensifikasi bahan budidaya atau diversifikasi olahan berbagai bahan lokal yang dibentuk menyerupai emping melinjo, misalnya dengan campuran dedak halus, jagung, dan konsentrat ( Anggorodi, 1994 ).

\section{Materi Dan Metode}

Materi yang digunakan dalam penelitian ini adalah DOC ayam kampung sebanyak 80 ekor. DOC ayam kampung diperoleh dari usaha pembibitan ayam kampung C.V. Panca Murti, Kelurahan Tlogomas, Kota Malang. Bahan pakan penyusun ransum yang terdiri atas: jagung, dedak, konsentrat ayam pedaging (kode pakan: CP 511 produksi PT. Charoen Pokphand Indonesia), Tepung emping melinjo yang diperoleh dari industri pengolahan emping melinjo di Sidoarjo.Pakan penelitian diformulasikan berdasar kebutuhan nutrisi ayam kampung.Pakan dan air minum diberikan secara ad libitum.Kandang yang dipakai adalah kandang terbuat dari bambu dengan alas lantai dan sekam dengan ukuran kandang $1 \mathrm{~m} \times 1 \mathrm{~m}$ dengan ketinggian $70 \mathrm{~cm}$, kandang dibagi berdasarkan jumlah 4 perlakuan dan 4 ulangan, masing-masing berisi 6-7 ekor, yang terdiri dari 16 petak. Adapun peralatan yang digunakan selama penelitian adalah :Karung untuk menyimpan pakan. Timbangan skala $2 \mathrm{~kg}$ dan timbangan digital untuk menimbang pakan dan penimbangan pertambahan bobot badan ayam.Bak 1 buah untuk penampungan air minum dan baskom 4 buah yang berfungsi untuk mencampur pakan perlakuan.Tempat minum manual ukuran 16m sebanyak 32 buah.Tempat pakan manual dengan ukuran $75 \mathrm{~cm}$ sebanyak 20 buah.Lampu pijar 5 watt sebanyak 32 buah.Peralatan lainnya gelas ukur, alat kebersihan dan tenda.Pengukur suhu sebanyak 1 buah.

Metode yang digunakan dalam penelitian ini adalah percobaan biologis. Rancangan percobaan penelitian adalah Rancangan Acak Lengkap (RAL), jumlah perlakuan 4, meliputi:

$\mathrm{P}_{0}$ : Penggunaan tepung emping melinjo dalam ransum sebesar 0\% (kontrol)

$\mathrm{P}_{1}$ : Penggunaan tepung emping melinjo dalam ransum sebesar $5 \%$

$\mathrm{P}_{2}$ : Penggunaan tepung emping melinjo dalam ransum sebesar $10 \%$

$\mathrm{P}_{3}$ : Penggunaan tepung emping melinjo dalam ransum sebesar $15 \%$. 
Variabel yang diamati adalah:Variabel bebas ialah tepung Emping Melinjo dan variabel terikat ialah Kadar glukosa darah $(\mathrm{mg} / \mathrm{ml}$ ) dan Energi Metabolis ( kkal/kg ). Jenis penelitian ini ialah eksperimental dengan rancangan penelitian ialah Rancangan Acak Lengkap (RAL).Data dianalisis dengan mengggunakan analisis varians tunggal dengan taraf signifikansi 0,01. Apabila terdapat perbedaan atau perlakuan akan dilanjutkan dengan uji Duncan. Analisis data dilakukan dengan bantuan program SPSS 16.0 .

\section{Hasil Dan Pembahasan}

Berdasarkan analis ragam menunjukan bahwa penambahan tepung emping melinjo memberikan pengaruh sangat nyata $(\mathrm{P}<0,01)$ terhadap kadar Glukosa Darah dan Energi Metabolis tidak berpengaruh $(\mathrm{P}>0,05)$ yang terterah pada Tabel 1.

Tabel 1.Pengaruh Pakan Perlakuan Terhadap Rata Rata Kadar Glukosa Darah dan Energi Metabolis.

\begin{tabular}{lll}
\hline Perlakuan & $\begin{array}{c}\text { Kadar Glukosa Darah } \\
(\mathrm{mg} / \mathrm{ml})\end{array}$ & $\begin{array}{c}\text { Energi Metabolis } \\
(\mathrm{kkal} / \mathrm{kg})\end{array}$ \\
\hline P0 & $265 \pm 0,58^{\mathrm{c}}$ & $2.6660 \pm 816,629$ \\
P1 & $215 \pm 0,58^{\mathrm{a}}$ & $2.7042 \pm 138,50$ \\
P2 & $230 \pm 0,58^{\mathrm{b}}$ & $2.6908 \pm 136,80$ \\
P3 & $307,5 \pm 10,10^{\mathrm{d}}$ & $2.6142 \pm 101,47$ \\
P value & 0.00 & 0,716
\end{tabular}

Keterangan: Nilai rata - rata dengan superscript menunjukan bahwa masing - masing perlakuan berpengaruh sangat nyata terhadap glukosa darah $\mathrm{P}<0,01$., sedangkan pada energi metabolis menunjukan bahwa tidak berpengaruh $\mathrm{P}>0,05$.

\section{Pengaruh penggunaan Tepung Emping Melinjo ( Getum Gnemon) Terhadap Kadar Glukosa Darah.}

Berdasarkan hasil penelitian, penambahan level tepung emping melinjo memberikan pengaruh sangat nyata $(\mathrm{P}<0.01)$ terhadap kadar glukosa Darah. Level penambahan emping melinjo memberikan perbedaan terhadap kandungan kadar glukosa darah perlakuan. Kandungan kadar glukosa darah perlakuan P0, P1, P2, dan P3 adalah $14,9 \% ; 13,9 \% ; 12,8 \%$; dan $11,8 \%$ semakin rendah kandungan dalam pakan cenderung menurunkan nilai kadar gluksa darah. Rata-rata kadar glukosa Tabel 4 menunjukan bahwah kadar glukosa darah tertinggi terdapat pada perlakuan P3, ( 307,5) lalu P0, (265), P2 (230) dan terendah terdapat pada perlakuan P1, (215). 


\section{Pengaruh penggunaan Tepung Emping Melinjo ( Getum Gnemon) Terahadap Energi Metabolis.}

Berdasarkan hasil penelitian, penambahan level tepung emping melinjo tidak memberikan pengaruh pada Energi Metabolis $(\mathrm{P}>0,05)$. Hal itu disebabkan karena kebutuhan dalam pakan sudah terpenuhi.Level penambahan emping melinjo tidak memberikan pengaruh terhadap Energi Metabolis. Kandungan protein Energi Metabolis perlakuan P0, P1, P2, dan P3 adalah 14,9\%; 13,9\%; 12,8\%; dan 11,8\% Rata-rata kandungan Energi Metabolis pada tabel 4 menunjukan Energi Metabolis tertinggi terdapat pada perlakuan P1, $(270,42)$ lalu P0, $(266,60)$, P2, $(269,08)$ dan terendah terdapat pada perlakuan P3, $(261,42)$.

\section{Kesimpulan}

Berdasarkan hasil penelitian maka ditarik kesimpulan bahwa pemberian tepung emping melinjo ( Gnetum gnemon ) sebesar 15\% menghasilkan glukosa darah yang normal sebesar $307,5 \mathrm{mg} / \mathrm{dl}$ dan energi metabolis tidak memberikan pengaruh, di tinjau dari kadar glukosa darah dan energi metabolis pada ayam kampung.

Saran yang diberikan adalah perlu dilakukan penelitian lanjutan tentang penggunaan tepung emping melinjo sebagai bahan pakan alternatif untuk menggantikan jagung.

\section{Ucapan Terimakasih}

Ucapan terima kasih disampaikan kepada semua pihak terutama Laboratorium Lapang Fakultas Peternakan Universitas Kanjuruhan Malang yang telah banyak membantu sejak persiapan hingga terselenggaranya penelitian ini dengan baik.

\section{Daftar Pustaka}

Afria, 2013. Effect of Addition of Choline Chloride in Feed on Quail (Coturnix coturnix Japonica). Production Performance. Fakultas Peternakan. Universitas Brawijaya.

Anggorodi, R. 1994. Ilmu Makanan Ternak Umum. PT. Gramedia. Jakarta.

Aliudin dan D. Anggraeni, 2012. Nilai Tambah Emping Melinjo Melalui Teknologi Produksi Konvensional di Desa Menes Kecamatan Menes Kabupaten Pandeglang. Agrika Vol 6 No.1 
Apriyantono, A. 2002. Pengaruh pengolahan terhadap nilai gizi dan keamanan pangan. Seminar on-line Kharisma ke-2.

Aviagen, 2011. Optimizing Broiler Feed Convertion Ratio. Tech. Notes. Ross an Aviagen Brand.

Ballo, V. J. 1997. Studi metabolisme energi dan protein pada ayam kampung dan hasil persilangannya dengan ayam ras pedaging pada periode pertumbuhan .Tesis. Fakultas Pascasarjana. Institut Pertanian Bogor, Bogor.

Bhat R., and N. Yahya, 2014. Evaluating Belinjau (Gnetum gnemon L.) Seed Flour Quality as Base for Development of Novel Product and Food Formulation. Food Chem. (156)42-9. Doi: 10.1016/j.foodchem.2014.01.063.

Ditjennak, 2010. Statistika Peternakan. Direktorat Jenderal Peternakan. Kementerian Pertanian. Jakarta. 287 hal.

Diwyanto K., D. Zainuddin, T. Sartika, S. Rahayu, Djufri, C. Arifin, dan Cholil. 1996. Model Pengembangan Agribisnis. Komoditi Ternak Buras. Laporan Dirjennak bekerjasama dengan Balitnak.

Iskandar S., 2005. Strategi Pengembangan Ayam Lokal. Wartazoa, 16(4): 191-197.

Manner H.I, and C.R. Elevitch, 2006. Gnetum gnemon (gnetum). Species Profiles for Pacific Island Agroforestry. www.traditionaltree.org.

NRC, 1994. Nutrient Requirement of Poultry: Ninth Revised Edition. National Research Council. National Academy Press. Washington D.C.

Sartika T.B., R. Gunawan, Matondang dan P. Mahyudin, 2002. Seleksi Generasi Ketiga untuk Mengurangi Sifat Mengeram dalam Meningkatkan Produksi Telur Ayam Lokal. Laporan No. UAT/BRE/F.01/APBN/2001. Balai Penelitian Ternak. Bogor. Hal 1-9.

Shabrina A.U., Eko W., dan. M.H. Natsir., 2014. Efek Suplementasi Betain dalam Pakan Rendah Metionin Terhadap Penampilan Produksi Itik Mojosari Jantan. J. Nutrisi Ternak Vol.1 No.1: 27-33

Sulandri S.,M.S.A. Zein, S. Paryati dan T. Sartika., 2007. Taksonomi dan Asal-Usul Ayam Domestikasi Dalam: Keanekaragaman Sumber Daya Hayati Alam Lokal Indonesia: Manfaat dan Potensi. Diwyanto K., and Prijono S.N. (Eds). Pusat Penelitian Biologi. Lembaga Ilmu Pengetahuan Indonesia. Bogor. 25 hal.

Tillman, A.D., H. Hartadi, S. Reksohadiprodjo, S. Prawirokusumo, dan S. Lebdosoekojo. 1991. Ilmu Makanan Ternak Dasar. Cetakan kelima. Gadjah Mada UniversityPress, Yogyakarta.

Wahyu J., 2004. Ilmu Nutrisi Unggas. Yogyakarta. Gadjah Mada University Press.

Winendar H., S. Listyawati, and Sutarto, 2006. Daya Cerna Protein Pakan dan Pertambahan Berat Badan Ayam Broiler setelah Pemberian Pakan yang 


\section{Jurnal Sains Peternakan}

Vol 6 No 2, Desember 2018, 50-56

ISSN 2579-4450

Difermentasi dengan Effective Microorganisms-4 (EM-4). Bioteknologi 3(1): 1419. Doi: $10.13057 /$ biotek/c030103 